\title{
Antimicrobial Resistance of ESBL Producing Coliforms Isolated from Retail Meat Samples
}

\author{
Zahra Batool $^{1 *}$, Asma Haque ${ }^{1}$, Fatima Jalal and Yasra Sarwar ${ }^{2}$ \\ ${ }^{1}$ Department of Bioinformatics and Biotechnology, Govt. College University Faisalabad, Pakistan
}

${ }^{2}$ National Institute for Biotechnology and Genetic Engineering, Jhang Road, Faisalabad, Pakistan

"Corresponding author: Dr. Zahra Batool, Department of Bioinformatics and Biotechnology, Govt. College University Faisalabad, Pakistan, Tel: +923137250581; Email: batoolzara23@gmail.com

Rec date: May 31, 2016; Acc date: June 17, 2016; Pub date: June 24, 2016

Copyright: (c) 2016 Batool Z, et al. This is an open-access article distributed under the terms of the Creative Commons Attribution License, which permits unrestricted use, distribution, and reproduction in any medium, provided the original author and source are credited.

\begin{abstract}
Extended Spectrum Beta lactamases (ESBLs) are special enzymes which are found in groups and can hydrolyze the third generation cephalosporins. Their Production is the commonest cause of resistance to beta-lactam antibacterial agents among Gram-negative bacteria. There is spread of drug resistance among food animals due to the use of antimicrobials. Pathogens develop resistance in their animal reservoirs and then these resistant strains are transmitted to humans where they may cause infections which are difficult to treat. In this study the antimicrobial resistance due to ESBL producing coliforms in humans and in edible animal meat was examined. The main objective of this study was to determine the fact that a substantial increase in antimicrobial resistance posed by ESBL producing coliforms in humans is due to edible animal meat. Various chicken, meat and beef samples were collected from different sites in Faisalabad. The samples were enriched in Trypticase Soy Broth and were streaked on Nutrient Agar then on MacConkey Agar to check the presence of Gram negative bacteria. Gram Negative isolates were isolated by gram staining and biochemical test (Triple Sugar Iron; TSI). Antibiotic susceptibility testing was performed through disc diffusion method. In which $28 \%$ isolates were resistant to Cefixime, $20 \%$ to Ceftriaxone, $24 \%$ to Clavulanic acid and $30 \%$ to Cefotaxime. As the next step, a set of PCR was optimized for amplification of major genes of ESBL conferring resistance to selected antibiotics. As a result $20 \% \mathrm{Bla}$ (CTX-M), $4 \% \mathrm{Bla}(\mathrm{OXA}), 2 \%$ $\mathrm{Bla}(\mathrm{PER})$ and $1 \% \mathrm{Bla}(\mathrm{Ges})$ were amplified through PCR. These are the major genes of ESBL which are going to become more and more resistant towards the first, second and third generation cephalosporins.
\end{abstract}

Keywords: ESBL; E. coli; PCR

\section{Introduction}

There are many classes of antibiotics called as Beta lactam antibiotics; these antibiotics have many antibiotic agents in which Beta lactam nucleus is found that is the central part of their molecular structure. These antibiotics include monobatams, derivatives of penicillin, cepholosporins and carbapenems. Beta-lactam antibiotics accounts for the beta-lactam global antibiotic consumption is approximately $50 \%$ and such a huge consumption has exerted considerable selection for resistance [1]. There are some strains of bacteria which have Extended Spectrum Beta-Lactamase that are enzymes in nature and they bring about resistance to antibiotics like penicillin and the cephalosporins. ESBL enzymes are mostly produced by two bacteria - E. coli and Klebsiella pneumoniae. There are some clinically important bata lactamases called as carbapenemases which are going to spread in some species of Enterobacteriaceae. The first carbapenemase was found in isolated Klebsiela pneumonia strains [2]. The evolution process involve for the carbepenemase-production of Entrobacteriaceae is a big problem for treatment of any kind of human diseases $[3,4]$. The reason behind this problem is that some carbapenemases hydrolyze most of the bata lactams which includes carbapenems and aztreonam, which make these organisms reisistant towards many drugs. Furthermore, many kinds of carbapenemases are going to spread the species of Enterobacteriaceae worldwide.

In 1980s, the ESBL was used in different diseases which were caused by Gram negative bacteria and their extensive use resulted in evolution of resistance against the beta lactam antibiotics. The examples of such $\beta$-lactams with distinctive functional group are ceftazidime, ceftriaxone, cefotaxime and aztreonam which is the member of oxyimino-monobactam [5]. In the start of 1990s, blaCTX-M was found in some isolates of ESBL-producing coliforms from Europe. After that as a result of mobilization from Kluyvera spp, it was distributed on the plasmids of many Enterobacteriaceae species. They were observed in later on in Argentina, China and India after the first reports of CTX-M ESBL in Germany and France [6,7]. It is assumed that without selection of any kind of antibiotics, many mobile resistance genes will be lost and as a result of this lose, the host bacterium will return to a sensitive phenotype. Therefore, for the selection of mobile genetic elements, there is a major mechanism, called as Co selection.

There are some genes which have horizontal gene transfer from their hosts to others through plasmids from where, they were spread in and established CTX-M-15 as the globally-dominant ESBL [8]. The human evidence supported the selective pressure exerted by the use of oximino- $\beta$ - lactams for the evolutionary process of the ESBLs [9]. Today, it has been demonstrated by some scientists that there are some bacteria which carry CTX-M enzymes, and face great challenges for ceftazidime and cefotaxime and thus playing a vital and critical role in the evolution of said enzymes [10]. In the in vivo evolution of Extended Spectrum Beta Lactamases, the use of various beta-latams could be contributing a constant pressure [11]. Mutations that have occurred in AmpC-encoding genes, as a result of use could be increased their spectrum of activity to fourth seneration cephalosporins [12]. 
Recently ESBLs and AmpC beta lactamases are the clinical and epidemiological important enzymes, having capability of inactivation of the broad-spectrum cephalosporins and penicillin. In clinically important Enterobacteriaceae, production of these enzymes could represent an increasing problem which results in higher patient mortality and morbidity [13]. In few years, Salmonella species have evolved that are resistant to many antimicrobial agents. Fluoroquinolones are the important drugs for curification of gastrointestinal infections in humans. The resistance to this class of antimicrobial agents is linked with increased mortality and morbidity [14].

Now in few years some isolates of Gram negative bacteria have evolved that are resistant to oxyiminocephalosporins because of the production of extended spectrum lactamases [15].

In gram negative bacterial strains, the commonest cause of resistance to beta lactam antibacterial agents is the production of betalactamases. These enzymes reduced the utilization of Gram-negative infections of first and second-generation cephalosporins and ampicillin chemotherapy. So, the extended spectrum of cephalosporins were design to overcome which were caused by the beta-lactamase enzymes. Unfortunately, members of Enterobacteriaceae have increase resistance because of the production of extended-spectrum of betalactamases (ESBLS) [16]. Now attention is going to be paid to the resistance; occurred in the bacteria against many antibiotics in both human bodies and animals and a great threat for their impact morbidity and mortality due the resistant bacterial diseases [17]. Antimicrobial resistance can be a result of horizontal gene transfer and also of unlinked point mutations in the pathogen genome. The action of antimicrobials can be due to environmental pressure; that sometimes going to be occurred against different pathogens. Mutant bacteria that allows them to survive and live to produce to pass the trait to the offsprings leads to the fully resistant colony [18]. Furthermore a lot of studies have investigated the transfer of antimicrobial resistance between zoonotic pathogens and commensal bacteria found in the different ecological environment $[19,20]$. This study was performed to determine the fact that a substantial increase in antimicrobial resistance posed by ESBL producing coliforms in humans is due to edible animal meat. To determine that transfer the antimicrobial resistance between commensal bacteriain different ecological environments.

\section{Materials and Methods}

\section{Sample collection, storage, enrichment and purification}

Slaughter houses were visited 5 to 7 times throughout Faisalabad region, depending on meat availability. A total of 60 samples (chicken, mutton, beef, $n=20$ each) from various sites throughout Faisalabad region were collected. From a slaughter batch (a single farm) 5 (chicken, mutton, beef) samples were collected separately from the batch. Retail-level sample each of skin-on chicken (leg, wing, breast or thigh) and fresh ground mutton and beef were collected from them. Samples were collected aseptically in sterile plastic bags and were transported to the research laboratory of Department of Bioinformatics and Biotechnology and Research Lab, Department of Zoology, Wildlife \& Fisheries, Govt. College University Faisalabad. Placed in the refrigerator and processed within 18-24 hrs. The enrichment of samples was carried out by diluting them in Trypticase SoyBroth (TSB) and after that they were homogenized and incubated [21]. For isolation and Purification of bacterial culture Nutrient agar and MacConkey agar were prepared. After the enrichment of chicken samples, a loopful of bacteria was picked with sterile loop and was streaked on the nutrient agar plates under sterile conditions. Then plates were incubated overnight in the incubator at $37^{\circ} \mathrm{C}$. When bacterial colonies were appeared on nutrient agar plates, then a single isolated colony was picked up by the sterile loop from nutrient agar plate and was streaked on MacConkey Agar plate. Likewise all clear bacterial colonies were streaked on the MacConkey Agar plates and incubated at $37^{\circ} \mathrm{C}$ overnight. After incubation the different bacterial colonies were appeared on MacConkey Agar plates. The color and colony morphology was the characteristic of different colonies of Gram negative bacteria. In order to get the purified colonies of Gram negative bacteria, these were sub-cultured again and again on MacConkey Agar plates under sterile conditions.

\section{Gram staining}

The process of Gram Staining was carried out to confirm Gram negative bacterial colonies [22].

\section{Biochemical tests}

The isolated Gram negative bacteria were identified by using biochemical method of Triple sugar iron (TSI). Triple Sugar Iron was prepared according to the manufacturer instructions (Merck, Germany). Three $3 \mathrm{ml}$ of media was dispensed in each tube. Tubes were plugged with cotton and get autoclaved. Tubes were placed in slanting position and allowed to cool in such a way that after solidification the agar tubes were having an equal length of slant and butt. A single isolated colony selected from MacConkey agar plate was stabbed on TSI slant using a straight wire loop. After overnight incubation at $37^{\circ} \mathrm{C}$ the isolates were identified with their specific reactions on TSI

\section{DNA extraction from bacterial cultures}

Total genomic DNA from bacterial isolates was extracted from overnight culture in TSB by house modified phenol-chloroform based extraction method [23]. The integrity of the DNA was checked by $1 \%$ agarose gel electrophoresis and stored the DNA at $4^{\circ} \mathrm{C}$.

\section{Molecular detection}

After DNA extraction; ESBL isolates were confirmed on molecular basis by regular Polymerase Chain Reaction (PCR). ESBL isolates were confirmed on molecular basis by regular PCR method by using different set of primers targeting different ESBL genes.

CTX-M primers were used which gave a product of 593 bp [24]. Primer sequence was 5'-ATGTGCAGYACCAGTAARGTKATGGC-3' for CTX-F and 5' TGGGTRAARTARGTSACCAGAAYCAGCGG-3'for CTX-R.

Reagents for PCR were $2.5 \mu \mathrm{l}$ of 10X PCR buffer, $0.5 \mu \mathrm{l}$ of Taq Polymerase, $1.5 \mu \mathrm{l}$ of Magnesium chloride, $1.5 \mu \mathrm{l}$ of DNTPs, $1.5 \mu \mathrm{l}$ of Primer (F), $1.5 \mu \mathrm{l}$ of Primer (R), $19 \mu \mathrm{l}$ of Water. Thermal cycler conditions for PCR were Denaturation at $94^{\circ} \mathrm{C}$ for 5 minutes

Amplification at $30^{\circ} \mathrm{C}$ for 1 minute, $54^{\circ} \mathrm{C}$ for 1 minute, $72^{\circ} \mathrm{C}$ for 1 minute and Extension at $72^{\circ} \mathrm{C}$ for 5 minutes. Then OXA primers were used for amplification of bla genes of OXA type $\beta$-lactamase and expected product size 478 bp (Yan et al., 2006). 
Primer sequence 5'-AAGAAACGCTACTCGCCTGC-3' for OXA-2$\mathrm{F}$ and 5'-CCACTCAACCCATCCTACCC-3' for 0XA-2-R.

Reagents for PCR were $2.5 \mu \mathrm{l}$ of 10X PCR buffer, $0.5 \mu \mathrm{l}$ of Taq Polymerase, $1.5 \mu \mathrm{l}$ of Magnesium chloride, $0.75 \mu \mathrm{l}$ of DNTPs, $1.5 \mu \mathrm{l}$ of Primer (F), $1.5 \mu \mathrm{l}$ of Primer (R), $17 \mu \mathrm{l}$ of Water. Thermal cycler conditions for PCR were Denaturation at $94^{\circ} \mathrm{C}$ for 5 minutes, Amplification at $30^{\circ} \mathrm{C}$ for 1 minute, $54^{\circ} \mathrm{C}$ for 1 minute, $47^{\circ} \mathrm{C}$ for 1 minute and Extension at $72^{\circ} \mathrm{C}$ for 5 minutes. Thermal cycler conditions for PCR were Denaturation at $94^{\circ} \mathrm{C}$ for 5 minutesAmplification at $30^{\circ} \mathrm{C}$ for 1 minute, $54^{\circ} \mathrm{C}$ for 1 minute, $72^{\circ} \mathrm{C}$ for 1 minute and Extension at $72^{\circ} \mathrm{C}$ for 5 minutes. GES primers were used for amplification of GES type $\beta$-lactamase and expected product size 864 bp (Vourli et al., 2004). Primer sequence was 5'-ATGCGCTTCATTCACGCAC-3' for GES-F and 5'-CTATTTGTCCGTGCTCAGG-3' for GES-R. Reagents for PCR were $2.5 \mu \mathrm{l}$ of 10X PCR buffer, $0.5 \mu \mathrm{l}$ of Taq Polymerase, $1.5 \mu \mathrm{l}$ of Magnesium chloride, $0.75 \mu \mathrm{l}$ of DNTPs, $1.5 \mu \mathrm{l}$ of Primer (F), $1.5 \mu \mathrm{l}$ of Primer (R), $17.5 \mu$ l of Water. Thermal cycler conditions for PCR were Denaturation at $94^{\circ} \mathrm{C}$ for 5 minutes, Amplification at $55^{\circ} \mathrm{C}$ for 1 minute, $54^{\circ} \mathrm{C}$ for 1 minute, $47^{\circ} \mathrm{C}$ for 1 minute and Extension at $72^{\circ} \mathrm{C}$ for 5 minutes. Thermal cycler conditions for PCR were Denaturation at $94^{\circ} \mathrm{C}$ for 5 minutes, Amplification at $54^{\circ} \mathrm{C}$ for 1 minute, $50^{\circ} \mathrm{C}$ for 1 minute, $72^{\circ} \mathrm{C}$ for 1 minute and Extension at $72^{\circ} \mathrm{C}$ for 5 minutes. PER primers were used for amplification of bla genes of PER type $\beta$ lactamase and expected product size 927 bp (Yan et al., 2006). Primer sequence was 5'-ATGAATGTCATCACAAAATG-3' for PER-F and 5'TCAATCCGGACTCACT-3' for PER-R. Reagents for PCR were $2.5 \mu \mathrm{l}$ of 10X PCR buffer, $0.5 \mu \mathrm{l}$ of Taq Polymerase, $1.5 \mu \mathrm{l}$ of Magnesium chloride, $0.75 \mu$ l of DNTPs, $1.5 \mu \mathrm{l}$ of Primer (F), $1.5 \mu \mathrm{l}$ of Primer (R), $17.5 \mu \mathrm{l}$ of Water. Thermal cycler conditions for PCR were Denaturation at $94^{\circ} \mathrm{C}$ for 5 minutes, Amplification at $55^{\circ} \mathrm{C}$ for 1 minute, $54^{\circ} \mathrm{C}$ for 1 minute, $47^{\circ} \mathrm{C}$ for 1 minute and Extension at $72^{\circ} \mathrm{C}$ for 5 minutes. Thermal cycler conditions for PCR were Denaturation at $94^{\circ} \mathrm{C}$ for 5 minutes, Amplification at $50^{\circ} \mathrm{C}$ for 1 minute, $54^{\circ} \mathrm{C}$ for 1 minute, $72^{\circ} \mathrm{C}$ for 1 minute and Extension at $72^{\circ} \mathrm{C}$ for 5 minutes. DNA fragments amplified by regular PCR were fractioned on $1.5 \%$ agarose gel.

\section{Antibiotic susceptibility testing}

Antimicrobial susceptibility test was performed by disc diffusion method. Four drugs were used including ceftriaxime, Cefixime, Ceftriaxone and Ceftazidime and results were then interpreted by following the guidelines of CLSI [25-31].

\section{Results}

Among 80 isolates, 50 Gram negative bacteria were isolated on MacConkey agar plates. There were different species of bacteria on Nutrient agar plates. After streaking on MacConkey agar; Gram negative bacteria showed pink colonies. Gram negative bacteria on MacConkey agar included Escherichia coli and Klebsiella pneumoniae. Different species of Bacteria isolated on MacConkey Agar. There were 37 isolates of $E$. coli; showed typical large rose pink and non mucoid colonies on MacConkey agar. There were twenty isolates of Klebsiella pneumoniae, showed rich growth on MacConkey agar. After separation; isolates were subjected to Gram staining and eighty Gram negative bacteria were confirmed by it. Isolates were identified biochemically on TSI agar slants. All bacteria showed their specific color change with gas production. Acidic butt and acidic slant with gas production were shown by $E$. coli and K. Pneumoniae but Klebsiella had slant color and gas production somewhat different from E. coli. By Disc Diffusion method ;out of 50 Gram negative bacteria 28\% isolates were resistant to Cefixime, $20 \%$ to Ceftriaxone, $24 \%$ to Clavulanic acid and $30 \%$ to Cefotaxime. The isolated ESBL producers were also subjected to molecular based identification of ESBL genes. In which $20 \% \mathrm{Bla}$ (CTX-M), 4\% Bla(OXA), 2\% Bla(PER) and $1 \%$ Bla(Ges) were amplified through PCR.

\section{Conclusion}

So it is very important for us to follow prompt and specific treatment options to control the emergence of drug resistance and to avoid the treatment failure as it may enhance the socioeconomic problems in our country and also worldwide.

\section{References}

1. Livermore DM (1998) Beta-lactamase-mediated resistance and opportunities for its control. J Antimicrob Chemother 41 Suppl D: 25-41.

2. Nordmann P, Cuzon G, Naas T (2009) The real threat of Klebsiella pneumoniae carbapenemase-producing bacteria. Lancet Infect Dis 9: 228-236.

3. Struelens MJ, Monnet DL, Magiorakos AP, O'Connor FS, Giesecke J (2010) New Delhi metallo-beta-lactamase 1-producing Enterobacteriaceae: emergence and response in Europe. Euro Surveill 15: 32-34.

4. Walsh TR (2008) Clinically significant carbapenemases: an update. Curr Opin Infect Dis 21: 367-371.

5. Bradford PA (2001) Extended-spectrum? -lactamases in the 21st century: characterization, epidemiology, and detection of this important resistance threat. Clinical Microbiology Reviews, 14: 933-951.

6. Ensor VM, Shahid M, Evans JT, Hawkey PM (2006) Occurrence, prevalence and genetic environment of CTX-M beta-lactamases in Enterobacteriaceae from Indian hospitals. J Antimicrob Chemother 58: 1260-1263.

7. Chanawong A, M'Zali FH, Heritage J, Xiong JH, Hawkey PM (2002) Three cefotaximases, CTX-M-9, CTX-M-13, and CTX-M-14, among Enterobacteriaceae in the People's Republic of China. Antimicrob Agents Chemother 46: 630-637.

8. Carattoli A (2009) Resistance plasmid families in Enterobacteriaceae. Antimicrob Agents Chemother 53: 2227-2238.

9. Gniadkowski M (2008) Evolution of extended-spectrum beta-lactamases by mutation. Clin Microbiol Infect 1: 11-32.

10. Novais A, Comas I, Baquero F, Cantón R, Coque TM, et al. (2010) Evolutionary trajectories of beta-lactamase CTX-M-1 cluster enzymes: predicting antibiotic resistance. PLoS Pathog 6: e1000735.

11. Blazquez J, Morosini MI, Negri MC, Baquero F (2000) Selection of naturally occurring extended-spectrum TEM beta-lactamase variants by fluctuating beta-lactam pressure. Antimicrob Agents Chemother 44: 2182-2184.

12. Ahmed AM, Shimamoto $\mathrm{T}$ (2008) Emergence of a cefepime- and cefpirome-resistant Citrobacter freundii clinical isolate harbouring a novel chromosomally encoded AmpC beta-lactamase, CMY-37. Int J Antimicrob Agents 32: 256-261.

13. Paterson DL, Bonomo RA (2005) Extended-spectrum beta-lactamases: a clinical update. Clin Microbiol Rev 18: 657-686.

14. Aarestrup FM, Wiuff C, Mølbak K, Threlfall EJ (2003) Is it time to change fluoroquinolone breakpoints for Salmonella spp.? Antimicrob Agents Chemother 47: 827-829.

15. Bauernfeind A, Casellas JM, Goldberg M, Holley M, Jungwirth R, et al. (1992) A new plasmidic cefotaximase from patients infected with Salmonella typhimurium. Infection 20: 158-163.

16. Livermore DM (1995) beta-Lactamases in laboratory and clinical resistance. Clin Microbiol Rev 8: 557-584.

17. White GD (2006) Antimicrobial resistance in pathogenic Escherichia coli from animals. American society of microbiology. 
Citation: Batool Z, Haque A, Jala F, Sarwar Y (2016) Antimicrobial Resistance of ESBL Producing Coliforms Isolated from Retail Meat Samples. J Biom Biostat 7: 316. doi:10.4172/2155-6180.1000316

Page 4 of 4

18. Ochiai K, Yamanaka T, Kimura K, Sawada O (1959) Inheritance of drug resistance between shigella starains and between Shigella and E. coli starins. Hihon Iji Shimpor 34: 1861-1862.

19. Mathew AG, Liamthong S, Lin J, Hong Y (2009) Evidence of class 1 integron transfer between Escherichia coli and Salmonella spp. on livestock farms. Foodborne Pathog Dis 6: 959-964.

20. Poppe C, Martin LC, Gyles CL, Smith RR, Boerlin P (2005) Acquisition of resistance to extanded-spectrum caphalosporine by salmonella and E. Coli in the intestinal tract of turkey poults. Applied and Environmental Microbiology 71: 1184-1192.

21. Ewing WH (1986) Edwrads and Ewing's identification of the Enterobacteriaceae. Elsevier Science Publishing Co Inc, New York.

22. Gram HC (1884) " $\{$ U $\}$ ber die isolierte Fl" $\{a\}$ rbung der Schizomyceten in Schnitt- und Trokenpr" \{a\} paraten. Fortschr. 185-189.

23. Smbrook J, Fritsch EF, Maniatis T (1989) Molecular cloning: a laboratory manual. (2ndeds) Cold Spring Harbor Labortary, USA

24. Twum-Danso K, Grant C, al-Suleiman SA, Abdel-Khader S, al-Awami MS, et al. (1992) Microbiology of postoperative wound infection: a prospective study of 1770 wounds. J Hosp Infect 21: 29-37.

25. Clinical and laboratory standard institute (2011) Performance standards for antimicrobial susceptibility testing: Fifteenth informational supplement, CLSI, Wayne, PA.
26. Liu PK, Tung JC, Ke SC, Chen SL (1998) Molecular Epidemiology of Extended-Spectrum ß-Lactamase-producing Klebsiella pneumoniae Isolates in a District Hospital in Taiwan. Journal of Clinical Microbiology 36: 759-2762.

27. Poirel L, Pitout JD, Nordmann P (2007) Carbapenemases: molecular diversity and clinical consequences. Future Microbiol 2: 501-512.

28. Struelens MJ, Monnet DL, Magiorakos AP, Santos O'Connor F, Giesecke J, et al. (2010) New Delhi metallo-beta-lactamase 1-producing Enterobacteriaceae: emergence and response in Europe. Euro Surveill 15.

29. Vourli S, Giakkoupi P, Miriagou V, Tzelepi E, Vatopoulos AC, et al. (2004) Novel GES/IBC extended-spectrum beta-lactamase variants with carbapenemase activity in clinical enterobacteria. FEMS Microbiol Lett 234: 209-213.

30. Holzbauer, Chiller T (2006) Antimicrobial resistance in bacteria of animal origin. Emerging infectious diseases 63: 145-166.

31. Yan JJ, Tsai SH, Chuang CL (2006) OXA type beta lactamase among ES cephalosporin resistant Pseudomonas aerogenosa isolates ina university hospital in southern Taiwan. J Microbiol Immunol Infect 39: 130-131. 